\title{
Review \\ Selective Laser Trabeculoplasty in the Treatment of Ocular Hypertension and Open-Angle Glaucoma: Clinical Review
}

\author{
Aleksandra Zgryźniak ${ }^{1}$, Joanna Przeździecka-Dołyk ${ }^{2,3, *(D)}$, Marek Szaliński 1,3 and Anna Turno-Kręcicka ${ }^{1,3}$ \\ 1 Clinic of Ophthalmology, University Teaching Hospital, ul. Borowska 213, 50-556 Wroclaw, Poland; \\ klo@usk.wroc.pl (A.Z.); marek.szalinski@umed.wroc.pl (M.S.); anna.turno-krecicka@umed.wroc.pl (A.T.-K.) \\ 2 Department of Optics and Photonics, Wroclaw University of Science and Technology, wyb. Stanislawa \\ Wyspianskiego 27, 50-370 Wroclaw, Poland \\ 3 Department of Ophthalmology, Wroclaw Medical University, ul. Borowska 213, 50-556 Wroclaw, Poland \\ * Correspondence: joanna.przezdziecka-dolyk@pwr.edu.pl or Joanna.przezdziecka-dolyk@umed.wroc.pl
}

check for

updates

Citation: Zgryźniak, A.;

Przeździecka-Dołyk, J.; Szaliński, M.;

Turno-Kręcicka, A. Selective Laser

Trabeculoplasty in the Treatment of

Ocular Hypertension and

Open-Angle Glaucoma: Clinical

Review. J. Clin. Med. 2021, 10, 3307.

https: / / doi.org/10.3390/

jcm10153307

Academic Editor: Paolo Fogagnolo

Received: 11 June 2021

Accepted: 23 July 2021

Published: 27 July 2021

Publisher's Note: MDPI stays neutral with regard to jurisdictional claims in published maps and institutional affiliations.

Copyright: (c) 2021 by the authors. Licensee MDPI, Basel, Switzerland. This article is an open access article distributed under the terms and conditions of the Creative Commons Attribution (CC BY) license (https:/ / creativecommons.org/licenses/by/ $4.0 /)$.

\begin{abstract}
Selective laser trabeculoplasty (SLT) is a glaucoma treatment that reduces intraocular pressure (IOP). Its mechanism is based on the biological effects of the selective application of laser energy to pigmented trabecular meshwork (TM) cells, resulting in increased outflow facility. Herein, we review current publications on SLT and summarize its efficacy and safety for different indications in open-angle glaucoma (OAG) and ocular hypertension (OHT) treatment. SLT effectively reduces IOP when used as a primary treatment. In patients whose IOP is medically controlled, SLT helps to reduce medication use, and when maximally tolerated topical therapy is ineffective, SLT facilitates the realization of the target IOP. SLT is a repeatable procedure for which the vast majority of complications are mild and self-limiting. With effective IOP reduction, low complication rates and the potential to repeat the procedure, SLT offers the possibility of delaying the introduction of medical therapy and other more invasive treatment modalities while simultaneously avoiding the accompanying complications. With this knowledge, we suggest that SLT be considered as an essential primary treatment option in OAG and OHT, switching to other treatment modalities only when laser procedures are insufficient for achieving the required target IOP.
\end{abstract}

Keywords: selective laser trabeculoplasty; ocular hypertension; open-angle glaucoma; glaucoma treatment; first-line glaucoma treatment; glaucoma; quality of life; intraocular pressure

\section{Introduction}

Intraocular pressure (IOP) is the only modifiable risk factor in the development and progression of glaucomatous optic neuropathy [1,2]. Therefore, decreasing IOP is a fundamental objective of glaucoma treatment. In addition to pharmacotherapy and incisional surgery, laser therapy has been widely used in glaucoma treatment for many years. In 1995, Latina and Park introduced SLT and proved that laser treatment could be applied selectively to pigmented trabecular meshwork (TM) cells [3]. In contrast to argon laser trabeculoplasty (ALT), the previous standard treatment, SLT avoids thermal damage to adjacent non-pigmented structures [4]. The Food and Drug Agency (FDA) approved the procedure in 2002, and since that time, it has become a widely used treatment option as both a primary and adjunctive treatment for most types of glaucoma. The results of published clinical trials provide a high level of evidence of the efficacy and safety of SLT for several indications. We suggest that SLT be considered as an important treatment option at different stages of glaucoma.

\section{Methods}

The aim of this paper is to summarize key clinical points associated with different indications of SLT used in ocular hypertension (OHT) and open-angle glaucoma (OAG) patients (see Supplementary Materials for the database search strategy and discussion). 
After removing duplicate studies, we selected 62 published reports for our analysis. We narrowed our review to publications from the past 10 years that address the efficacy and safety of clinical treatment. Additionally, we performed a side search summarizing the possible use of SLT in the closed-angle glaucoma. As this is only a possible introduction for future synthetic research, we just indicated the most important studies and did not perform a full search strategy on this subject.

\section{Mechanisms of Action}

Although SLT has been widely used for years, the exact mechanisms by which it reduces IOP have still not been established. Several studies have shown possible cellular, histopathological and biological effects in TM and Schlemm's canal cells.

\subsection{Cellular and Histopathological Changes}

In their historical in vitro study in 1995, Latina and Park showed that selective photothermolysis could be applied to TM cells. The researchers focused on the ability of melanin, a chromophore, to absorb laser energy with specific parameters. Mixed cultures of pigmented and non-pigmented TM cells were exposed to a $532 \mathrm{~nm}$ Q-switched Nd:YAG laser. The study showed that with a pulse duration of $10 \mathrm{~ns}$ to $1 \mu \mathrm{s}$, both melanosomes and lysosomal membranes in the pigmented TM cells were disrupted. At the same time, mitochondria lost their structure. These effects were limited to pigmented TM cells. The exposure times used were shorter than the melanin thermal relaxation time, thus avoiding collateral thermal damage to the adjacent non-pigmented TM cells [3,5,6].

A study by Kramer et al. compared post-SLT and post-ALT changes in the uveal meshwork portion of the TM in autopsy eyes. While TM structures were observed to be disrupted with evident coagulative damage (ablation craters) after ALT, SLT-treated tissues showed minimal mechanical damage. Instead, ultrastructural changes, such as the cracking of intracytoplasmic pigment granules and the disruption of TM endothelial cells, were observed [4]. The results of the study by SooHoo et al. were consistent with the work by Kramer et al. in terms of the ultrastructural effects of SLT applied with standard low energies to cadaveric corneal rims. However, tissues treated with energy of $2 \mathrm{~mJ}$ showed signs of destruction and scrolling of trabecular beams at the edges of laser burns [7]. Because the lower energies in the SLT method cause almost no coagulative damage, the mechanical effects are minimized. The biological effects that we describe below appear to be a plausible explanation of the SLT mechanism of action.

\subsection{Biological Changes}

SLT has been proven to evoke changes in cellular activity, such as the secretion of different interleukins and metalloproteinases as well as the recruitment of monocytes, leading to the remodeling of the juxtacanalicular extracellular matrix and increasing outflow facility.

Some studies on ALT mechanisms have shown laser-induced biological effects in TM cells. Parshley et al. hypothesized that a turnover of the trabecular extracellular matrix that is regulated by metalloproteinases plays a crucial role in regulating aqueous humor outflow. Among the metalloproteinases secreted by TM cells, stromelysin-1 (metalloproteinase3, MMP-3) has the broadest substrate specificity. It degrades the globular domains of proteoglycan core proteins, laminin, fibronectin, type IV collagen and other proteins. Researchers evaluated the MMP-3 activity and levels as well as its mRNA levels in lasertreated organ cultures that mimicked the human TM. The study showed a several-fold increase in all parameters at different time points after laser trabeculoplasty. These increases were mainly observed in the insert and juxtacanalicular regions of the meshwork. Bradley et al. showed that MMP-3 secretion in the TM after laser treatment is mediated by increased secretion of the inflammatory interleukins IL-1 $\beta$ and TNF- $\alpha$ [8,9]. SLT may induce similar effects in the TM.

Lee et al. observed an increase in MMP-3 secretion from co-cultures of pigmented and non-pigmented human TM cells after SLT. Interestingly, isolated non-pigmented TM cells 
showed no response to SLT treatment in terms of MMP-3 secretion. Conversely, MMP-3 secretion from isolated pigmented TM cells declined after SLT. A possible explanation is that laser-treated cells that undergo cell death stimulate adjacent non-treated cells to secrete MMPs. This study also examined the SLT effects on cellular activity and revealed a decline in cellular metabolic activity and an increase in necrosis and apoptosis after SLT in the tested co-cultures [10].

Another biological effect of SLT is the recruitment of monocytes, which influence outflow facility. Alvarado et al. observed an increased number of monocytes in human and monkey eyes treated with SLT. To investigate the effects of their recruitment, autologous macrophages were infused into the anterior chamber in rabbits, and an increase in outflow facility was observed. Additionally, this study showed that human monocytes and monocyte-secreted factors induced increased conductivity in human Schlemm's canal endothelial cells in vitro [11]. In another in vitro study, Alvarado et al. showed that the laser-induced increase in the permeability of Schlemm's canal cells was due to intercellular junction disassembly [12].

The main mechanisms described in the literature are summarized in Figure 1.

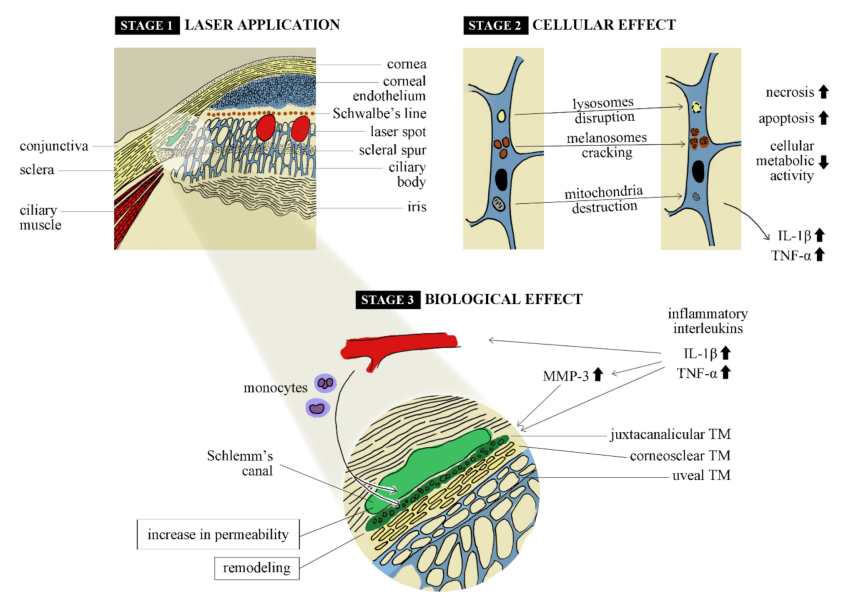

Figure 1. Summary of the trabecular meshwork tissue response induced by selective laser trabeculoplasty.

\section{Technique}

SLT is performed under topical anesthesia with the use of goniolens. A frequencydoubled q-switched $532 \mathrm{~nm}$ Nd:YAG laser with a pulse duration of $3 \mathrm{~ns}$ and spot size of $400 \mu \mathrm{m}$ is utilized. A laser beam is focused on the entire width of the TM, and the laser energy is titrated from $0.3 \mathrm{~mJ}$ until bubble formation becomes visible in the treatment area. Once the bubble is visible, the laser energy is decreased by $0.1 \mathrm{~mJ}$ until the bubble effect is minimized. Some clinicians prefer to see bubbles in only some of the spots. In the trials that we reviewed, the energies varied from 0.2 to $1.7 \mathrm{~mJ}$. Once the appropriate energy is established, treatment is continued over 90,180 or 360 degrees of the TM. In principle, 25 spots should be applied for every 90 degrees of the TM [5,13-15].

Since the introduction of the technique, several protocols concerning the treatment degree of the TM and the number of spots have been evaluated. Table 1 summarizes differences in the effectiveness of SLT in relation to the scope of the procedure performed (the number of quadrants of the circuit covered by laser spots). 
Table 1. Summary of the effectiveness of SLT in relation to the scope of the procedure performed (the number of quadrants of the circuit covered by laser therapy).

\begin{tabular}{|c|c|c|c|c|c|c|c|}
\hline Research & Type of Study & $\begin{array}{l}\text { Number of } \\
\text { Subjects }\end{array}$ & Diagnosis & Indications & IOP Reduction & $\begin{array}{l}\text { Differences in } \\
\text { Procedure }\end{array}$ & $\begin{array}{l}\text { Observation } \\
\text { Time }\end{array}$ \\
\hline \multirow{2}{*}{$\begin{array}{l}\text { Chen et al. } \\
2004 \text { [16] }\end{array}$} & \multirow{2}{*}{$\begin{array}{l}\text { Prospective, } \\
\text { single-masked } \\
\text { randomized } \\
\text { clinical trial }\end{array}$} & $\mathrm{N}_{90}=32$ & OAG, OHT & Adjunctive & $\begin{array}{l}5.1 \mathrm{mmHg}(1 \mathrm{mo}) \\
6.3 \mathrm{mmHg}(4 \mathrm{mo}) \\
6.2 \mathrm{mmHg}(7 \mathrm{mo})\end{array}$ & $\begin{array}{l}90 \text { degrees, } \\
\text { some patients } \\
\text { received ALT }\end{array}$ & Up to 7 months \\
\hline & & $\mathrm{N}_{180}=32$ & OAG, OHT & Adjunctive & $\begin{array}{l}4.2 \mathrm{mmHg}(1 \mathrm{mo}) \\
5.6 \mathrm{mmHg}(4 \mathrm{mo}) \\
7.1 \mathrm{mmHg}(7 \mathrm{mo})\end{array}$ & $\begin{array}{l}180 \text { degrees, } \\
\text { some patients } \\
\text { received ALT }\end{array}$ & Up to 7 months \\
\hline \multirow[b]{2}{*}{$\begin{array}{l}\text { Goyal et al. } \\
2010 \text { [17] }\end{array}$} & \multirow{2}{*}{$\begin{array}{l}\text { Prospective, } \\
\text { single-masked } \\
\text { randomized } \\
\text { clinical trial }\end{array}$} & $\mathrm{N}_{180}=18$ & $\begin{array}{c}\mathrm{OAG}=12 \\
\mathrm{OHT}=6\end{array}$ & Primary & $6.1 \mathrm{mmHg}(1 \mathrm{mo})$ & 180 degrees & 1 month \\
\hline & & $\mathrm{N}_{360}=19$ & $\begin{array}{c}\mathrm{OAG}=15 \\
\mathrm{OHT}=4\end{array}$ & Primary & $9.0 \mathrm{mmHg}(1 \mathrm{mo})$ & 360 degrees & 1 month \\
\hline \multirow{2}{*}{$\begin{array}{l}\text { Shibata et al. } \\
2012 \text { [18] }\end{array}$} & \multirow[t]{2}{*}{$\begin{array}{l}\text { Retrospective } \\
\text { cohort study }\end{array}$} & $\mathrm{N}_{180}=35$ & OAG & Additive & $2.6 \mathrm{mmHg}(6 \mathrm{mo})$ & 180 degrees & $\begin{array}{l}\text { Up to } \\
36 \text { months }\end{array}$ \\
\hline & & $\mathrm{N}_{360}=34$ & OAG & Additive & $5.6 \mathrm{mmHg}(6 \mathrm{mo})$ & 360 degrees & $\begin{array}{c}\text { Up to } \\
36 \text { months }\end{array}$ \\
\hline $\begin{array}{c}\text { Francis et al. } \\
2016 \text { [19] }\end{array}$ & $\begin{array}{l}\text { Open-label } \\
\text { prospective } \\
\text { study }\end{array}$ & $\mathrm{N}_{360}=137$ & POAG & Additive & $\begin{array}{c}4.1 \mathrm{mmHg} \\
(6-12 \mathrm{mo}) \\
3.5 \mathrm{mmHg} \\
(12-15 \mathrm{mo})\end{array}$ & 360 degrees & $\begin{array}{c}\text { Up to } \\
15 \text { months }\end{array}$ \\
\hline \multirow[t]{2}{*}{$\begin{array}{l}\text { Tawfique et al. } \\
2019 \text { [20] }\end{array}$} & \multirow[t]{2}{*}{$\begin{array}{l}\text { Prospective, } \\
\text { single-masked } \\
\text { randomized } \\
\text { clinical trial }\end{array}$} & $\mathrm{N}_{90}=32$ & $\begin{array}{c}\text { OAG, OHT, } \\
\text { XFG }\end{array}$ & $\begin{array}{l}\text { Primary or } \\
\text { Additive }\end{array}$ & $\begin{array}{l}\text { nd (only survival } \\
\text { analysis was } \\
\text { conducted }\end{array}$ & 90 degrees & $\begin{array}{c}\text { Up to } \\
24 \text { months }\end{array}$ \\
\hline & & $\mathrm{N}_{180}=35$ & $\begin{array}{c}\text { OAG, OHT, } \\
\text { XFG }\end{array}$ & $\begin{array}{l}\text { Primary or } \\
\text { Additive }\end{array}$ & $\begin{array}{l}\text { nd (only survival } \\
\text { analysis was } \\
\text { conducted) }\end{array}$ & 360 degrees & $\begin{array}{c}\text { Up to } \\
24 \text { months }\end{array}$ \\
\hline \multirow{2}{*}{$\begin{array}{l}\text { Özen et al. } \\
2020 \text { [21] }\end{array}$} & \multirow[t]{2}{*}{$\begin{array}{l}\text { Open-label } \\
\text { prospective } \\
\text { study }\end{array}$} & $\mathrm{N}_{180}=26$ & POAG & Additive & $\begin{array}{l}7.8 \mathrm{mmHg}(1 \mathrm{mo}) \\
9.0 \mathrm{mmHg}(3 \mathrm{mo}) \\
9.1 \mathrm{mmHg}(6 \mathrm{mo})\end{array}$ & 180 degrees & Up to 6 months \\
\hline & & $\mathrm{N}_{360}=26$ & POAG & Additive & $\begin{array}{c}8.5 \mathrm{mmHg}(1 \mathrm{mo}) \\
10.1 \mathrm{mmHg}(3 \mathrm{mo}) \\
10.3 \mathrm{mmHg}(6 \mathrm{mo})\end{array}$ & 360 degrees & Up to 6 months \\
\hline \multirow{2}{*}{$\begin{array}{l}\text { Nirappel et al. } \\
2021 \text { [22] }\end{array}$} & \multirow[t]{2}{*}{$\begin{array}{l}\text { Retrospective } \\
\text { cohort study }\end{array}$} & $\mathrm{N}_{180}=196$ & OAG, OHT & Additive & $\begin{array}{c}2.9 \mathrm{mmHg}(6 \mathrm{wk}) \\
3.0 \mathrm{mmHg}(12 \mathrm{mo}) \\
2.2 \mathrm{mmHg}(24 \mathrm{mo})\end{array}$ & 180 degrees & $\begin{array}{l}\text { Up to } \\
24 \text { months }\end{array}$ \\
\hline & & $\mathrm{N}_{360}=258$ & OAG, OHT & Additive & $\begin{array}{c}3.2 \mathrm{mmHg}(6 \mathrm{wk}) \\
3.4 \mathrm{mmHg}(12 \mathrm{mo}) \\
2.4 \mathrm{mmHg}(24 \mathrm{mo})\end{array}$ & 360 degrees & $\begin{array}{l}\text { Up to } \\
24 \text { months }\end{array}$ \\
\hline
\end{tabular}

mo-months; wk—weeks; OAG—open-angle glaucoma; OHT—ocular hypertension; POAG—primary open-angle glaucoma; nd—no data.

\section{Postoperative Treatment}

Depending on the clinician's practice, short-term anti-inflammatory and IOP-reducing topical treatments may be used after SLT. We found several studies evaluating the impact of postoperative treatment on the efficacy and safety of SLT.

\subsection{Anti-inflammatory Therapy}

The "Steroid After Laser Trabeculoplasty (SALT)" trial was a double-masked, randomized, placebo-controlled trial that evaluated the impact of post-SLT medication on IOP reduction in POAG, exfoliative glaucoma (XFG) and OHT patients. The study was performed on 96 eyes of 85 patients, who were randomized into three groups for treatment with $0.5 \%$ ketorolac, $1.0 \%$ prednisolone or saline tears four times a day for 5 days after SLT. Twelve weeks after the SLT procedure, IOP had decreased by $-6.2 \pm 3.1 \mathrm{mmHg}$, $-5.2 \pm 2.7 \mathrm{mmHg}$ and $-3 \pm 4.3 \mathrm{mmHg}$ in the ketorolac, prednisolone and placebo groups, respectively. The differences between the treatment and placebo groups were statistically significant. Post-SLT treatment with prednisolone or ketorolac proved to positively contribute to the IOP-lowering effect [23]. 
The results of the SALT study contradict those of a similarly constructed study by Jinapriya et al., who found no statistically significant difference between groups treated with $1.0 \%$ prednisolone acetate, $0.5 \%$ ketorolac tromethamine and artificial tears at the one-month follow-up. In this study, SLT was less effective, and the most probable reason was a low baseline IOP $[23,24]$. Similar results were shown in a prospective randomized trial by de Keyser et al., who performed SLT in both eyes of 66 patients. One eye received $0.1 \%$ indomethacin or $0.1 \%$ dexamethasone, whereas the other did not receive any antiinflammatory treatment. The researchers found no statistically significant difference in terms of IOP reduction or topical inflammatory reactions between groups at the 6-month follow-up [25,26]. Similarly, in a retrospective review, Rebenitsch et al. compared the use of loteprednol for 5-7 days after $360^{\circ}$ SLT against treatment without loteprednol and observed no statistically significant difference in the absolute or percentage decrease in IOP [27].

\subsection{Preventing IOP Spikes}

IOP spikes are common adverse events that occur shortly after the laser trabeculoplasty procedure. Several studies have been conducted on the prevention of elevated postoperative IOP. An in-depth review by Zhang et al. was published in 2017, which included 22 randomized clinical trials, with 2112 participants in total. The review indicated that perioperative medication prevented IOP spikes within 2-24 h after laser trabeculoplasty. The study also demonstrated that alpha-2-agonists and pilocarpine were effective. The certainty of the evidence was mainly graded moderate to low [28,29].

\subsection{Conclusions}

Taking the available literature into consideration, it is not possible to establish clear recommendations for post-SLT medication. In terms of long-term IOP-lowering effects, patients might benefit from short-term therapy with prednisolone acetate or ketorolac. Apraclonidine, brimonidine and pilocarpine are significantly more effective than a placebo in preventing postoperative IOP spikes.

\section{Efficacy of Treatment}

The efficacy of SLT in OAG and OHT treatment has been evaluated in a number of trials, which can be divided in accordance with the indications for which the SLT was used.

\subsection{SLT as First-line Therapy}

Published in 2019, the Laser in Glaucoma and ocular HyperTension (LIGHT) study was a multi-center, unmasked, randomized trial that evaluated and compared the healthrelated quality of life (HRQoL), clinical efficacy, cost-effectiveness and safety between SLT and IOP-lowering eye drops. The subjects were newly diagnosed treatment-naïve patients with OAG or OHT who were monitored over a 3-year period. There were 356 patients randomized in the laser-first group and 362 patients assigned to the medication-first group. For patients with OHT, success was defined as IOP $<25 \mathrm{mmHg}$ and $>20 \%$ IOP reduction. For OAG patients, unlike in other studies, which have often defined the success rate solely as $>20 \%$ reduction in IOP from the baseline, a target IOP was established at the beginning of the study for each patient in accordance with glaucoma severity. During the observation, target IOP was reduced, in cases that manifested deterioration despite IOP being at or below target. In cases that remained stable despite IOP being slightly above target, target IOP was revised and higher values at which no deterioration was observed were accepted. Follow-up intervals and excess treatment were determined on the same basis. During the observation period, decision-making about subsequent treatment steps was supported by a defined protocol and digital tool. The study was meticulously designed to make the results both more accessible to clinicians and easy to use in real-life situations. In the laser-first group, patients underwent SLT, which could be repeated once during follow-up. If IOP control was insufficient, patients were further treated with medication. In the medicationfirst group, patients were treated with topical medications in a stratified manner, whereby 
a prostaglandin analogue, beta-blocker, topical carbonic anhydrase inhibitor and alphaadrenoceptor agonist were offered as the first, second, third and fourth treatment choice, respectively [13,14].

HRQoL was assessed using the EuroQol Five Dimension Five Level Scale (EQ-5D5L) questionnaire, which evaluates five dimensions of quality of life: mobility, self-care, usual activities, pain and discomfort, and anxiety and depression. At 36 months, the score was not significantly different between the groups (adjusted mean difference (laser first-medicine first) $0.01,95 \% \mathrm{CI}-0.01$ to $0.03 ; p=0.23$ ) [30]. Of the eyes treated with primary SLT, 95\% reached the target IOP by the end of the follow-up period. Of this group, $78.2 \%$ of the eyes required no additional medication, which showed that $74.2 \%(95 \%$ CI 69.3-78.6) of eyes in the laser-first arm achieved eyedrop-free IOP control for at least 3 years. In the medication-first group, $93.1 \%$ of eyes were at the target IOP at 36 months, and of these eyes, $64.6 \%$ required only one type of medication. In the laser-first group, the number of treatment escalations, as well as the number of required IOP-lowering and cataract surgeries, was lower than in the medicine-first arm. The difference was critical in the number of trabeculectomies (0 in laser-first arm vs. 11 in medication-first arm). Post-SLT patients did not report any sight-threatening adverse events. After the procedure, only six IOP spikes ( $>5 \mathrm{mmHg}$ ) were observed, whereas transient discomfort, blurred vision, photophobia and hyperemia were reported by $34.4 \%$ of patients. Systemic adverse events were comparable between the laser-first and medication-first groups. SLT resulted in a greater quality-adjusted life-year gain at a lower cost than medical therapy, but the difference was not significant $(p=0.286)[13,14]$.

The trial proved SLT to be a clinically effective, cost-effective and safe alternative to eye drops as primary therapy in patients with OAG or OHT. In conclusion, the researchers stated that SLT should be offered as first-line therapy, supporting a change in clinical practice. Due to its exceptional design, which enabled the replication of real-world practice while tailoring the therapy to the patient, the LIGHT study is of outstanding importance in clinical practice $[13,14]$. Notably, the use of SLT as first-line therapy substantially lowers the non-compliance risk rate and decreases the rate of side effects, thus improving the probability that patients are able to achieve the prespecified target IOP.

In a post hoc analysis of the LIGHT study, Garg et al. compared the clinical efficacy of primary SLT in treatment-naïve patients with OAG and OHT. The researchers reported that primary SLT was a comparably effective IOP-lowering treatment in OAG and OHT patients $[25,31]$.

The results of the LIGHT trial were included in a meta-analysis by Chi et al. with two other trials in treatment-naïve patients, and similar results were observed in terms of the IOP reduction efficacy of SLT [32-34].

The results of the LIGHT study contradict those of the Glaucoma Intensive Treatment Study (GITS) trial by Ang et al., which was published in 2020. It compared SLT with escalated medication in POAG and XFG patients, and a better response in terms of decreased IOP was observed in the Medication group at the 12 -month (62.3\% vs. $45.5 \%)$ and 24 -month follow-up $(72.1 \%$ vs. $53.4 \%)$. At the end of the observation period, the success rate of medication was $18.6 \%(95 \%$ CI $3.0 \%-34.3 \%, p=0.022)$, which was higher (as an absolute difference) than that in the SLT group. Compared with the LIGHT study, the sample size of GITS was smaller. With 167 patients randomized, GITS did not reach the target size of 386 patients. Treatment success was defined as $>25 \%$ IOP reduction from the baseline. In contrast to the LIGHT study, in which SLT covered $360^{\circ}$ of the TM, in the GITS trial, SLT was applied to $180^{\circ}$ of the TM [13-15].

An interesting outcome was achieved in Kiddee and Atthavuttisilp's assessment of the post-SLT reduction in diurnal IOP fluctuations compared with the effect of medication (travoprost) in POAG and normal-tension glaucoma (NTG). In this randomized singlemasked study, SLT was introduced as first-line therapy, and the authors did not find any statistical difference in IOP reduction (median reduction in IOP was $3.7 \mathrm{mmHg}$ and $4.1 \mathrm{mmHg}$ in SLT and Travoprost groups, respectively) between groups according to the 
type of glaucoma. The main outcome, which was success in reducing fluctuations, was achieved in $75 \%$ and $92 \%$ of subjects in the SLT and Travoprost groups, respectively. In addition, the rate of reduction in diurnal fluctuations was lower in the NTG group than in the POAG group [35].

In a recently published retrospective study by Ansari et al., SLT was found to effectively reduce IOP in POAG treatment-naïve patients over a 10-year observation period. The trial evaluated 108 eyes of 54 patients. With SLT repeated as required, the success rate of treatment, defined as both $>20 \%$ IOP reduction compared with the pre-treatment value and IOP $<19 \mathrm{mmHg}$, was $98 \%$ at year $1,89 \%$ at year 5 and $72 \%$ at year 10 . Treatment failure was most common at 3 years. During the observation period, $60 \%$ of patients required additional SLT procedures [36].

In summary, we consider SLT to be a promising first-line therapy option that can postpone the need to administer topical medications that may, on the one hand, cause allergic reactions and, on the other, cause changes in the anterior segment of the eye or the entire eye socket [29,37-39]. Patients are inclined to consent to treatments that provide an option to be medically independent. In this respect, SLT appears to be an ideal solution since the balance between benefits and complications is acceptable and favorable.

\subsection{Replacement Therapy}

The vast majority of trials have focused on post-SLT reduction in IOP. Fewer studies have evaluated the potential of SLT to reduce topical medication as the main outcome measure. One of the main concerns of glaucomatous patients, however, is the number of medications that they are expected to self-administer on a daily basis. Additionally, non-compliance is largely due to the inadequate administration of eye drops, an inability to adhere to a strict regimen and multiple formulations or an unwillingness to be treated with eye drops. Patients tend to prefer single or even multiple laser procedures if they will "free" them from eye drops.

A study by Francis et al. evaluated 66 patients with controlled POAG and XFG on topical medication. The primary outcome measure was the reduction in the number of medications after SLT over the course of a one-year observation period. The mean reduction in medications from the baseline was $2.0(1.8-2.3)$ at 6 months, which represents 95\% confidence, and $1.5(1.27-1.73)$ at 12 months $(p<0.0001)[19,40]$.

A prospective, comparative, interventional case series by Tufan et al. was designed to assess the medication-reducing effect of SLT in one eye compared with the fellow eye, which continued treatment with a fixed combination with timolol. In the study groups, 22 eyes underwent $180^{\circ}$ SLT, and 18 eyes received $360^{\circ}$ SLT. Forty fellow eyes made up the control group. At the 6-month follow-up, the study showed no statistically significant differences between groups $(p<0.001)$ [41].

In 2018, de Keyser et al. published the results of their prospective randomized clinical trial on 286 eyes of 143 OAG and OHT patients on topical medication with controlled IOP who received SLT as replacement therapy. Patients were randomized into two groups: an SLT group and a control group that continued topical medication. All patients who underwent SLT reduced their medication, of which $77 \%$ needed no medication after 12 months of observation, and 74\% no longer needed medication after 18 months. The mean reduction in medication was 1.15 after 12 months and 1.21 after 18 months [42].

In another trial, de Keyser et al. assessed changes in the quality of life of patients after the use of SLT as replacement therapy. The SLT group consisted of 64 patients, and the control group included 61 patients that continued medical therapy. Groups were followed for at least 6 months. While the mean IOPs remained unchanged in both groups during follow-up, the mean number of medications in the SLT group was reduced from 1.56 to 0.42 and 0.33 at 6 and 12 months, respectively. In the SLT group, punctate keratitis was observed in $35.94 \%$ of patients at the baseline, $14.06 \%$ at the 6 -month follow-up $(p=0.14)$ and $12.24 \%$ at 12 months. The quality-of-life questionnaire included 15 questions about the perceived effectiveness of the treatment, its side effects, eye appearance changes, its convenience 
and the ease of administration of the eye drops. One year after SLT, all parameters were rated better by the treatment group than by the control group, with the difference being significant $(p<0.001)$. In this study, SLT was proven to be effective in reducing the number of medications, which resulted in an improvement of the treatment-related quality of life [43].

In summary, SLT is able to "free" patients from topical medication in approximately $70 \%$ of cases for 12-18 months after therapy, which results in an improvement of the quality of life and a reduction in topical complications.

\subsection{Adjunctive Therapy}

Besides reducing the number of drugs used in patients with well-controlled IOP, SLT may help to achieve IOP control in patients in whom medical therapy is insufficient. Patel et al. conducted a retrospective review of 67 glaucoma and ocular hypertension patients who had uncontrolled IOP on maximally tolerated medical therapy and underwent SLT as adjunctive therapy. Eight eyes that did not achieve the target IOP in the first 3 months of observation were excluded from the analysis. With success defined as either IOP reduction $>20 \%$ from the baseline or reduction in medication without additional laser or surgical intervention, the success rates were $62 \%, 50 \%$ and $32 \%$ after 1,3 and 5 years, respectively. The mean IOP (baseline $18.7 \mathrm{mmHg}$ ) was significantly reduced in $4-8$ weeks $(15.6 \mathrm{mmHg}$, $p<0.001)$ and at the 1-year follow-up $(16.8 \mathrm{mmHg}, p=0.005)$. Similarly, the mean number of medications was reduced significantly at 1-year, 3-year and 5-year follow-up $(p<0.001$, $p<0.001$ and $p=0.039$, respectively) [44].

A UK study that monitored the real-world outcomes of 831 SLT-treated eyes included an assessment of the efficacy of SLT in patients that used prostaglandin analogues. The study showed no difference in SLT failure between 449 patients using prostaglandin analogues and 75 patients using other medications (HR, 0.95; 95\% CI, 0.70-1.30; $p=0.76$ ) or 382 patients who did not use prostaglandin analogues (HR, 0.95; 95\% CI, 0.8-1.12; $p=0.56)$. Additionally, the researchers compared the IOP-lowering effect between 237 patients using prostaglandin analogues and 202 patients not using prostaglandin analogues whose data were available at the 12-18 month time point. The absolute reduction in the prostaglandin analogue group and the non-prostaglandin group was $3.6 \mathrm{mmHg}(95 \% \mathrm{CI}$, $2.9-4.2 ; p<0.0001)$ and $4.9 \mathrm{mmHg}(95 \% \mathrm{CI}, 4.2-5.6 ; p<0.0001)$, respectively. After adjusting for pre-SLT IOP, the difference was not significant $(p=0.81)$ [45].

The available literature shows that SLT has the potential to reduce IOP in patients whose IOP is uncontrollable with medication alone. The type of medication used before the procedure does not influence the rate of IOP reduction.

\subsection{Young Patients}

Because the IOP needs to be lowered throughout an individual's lifetime and the risk of intolerance to topical medication evolves with time, SLT can be an attractive option for patients with juvenile open-angle glaucoma. We found only two studies that evaluated SLT in patients under 40 years of age.

Gupta et al. observed 30 eyes of 30 patients diagnosed with juvenile open-angle glaucoma before the age of 40 . Patients on maximally tolerable medical therapy and IOPs above the target underwent SLT and were followed up for 12 months. The researchers found that IOP was reduced from $25.3 \pm 6.5$ at the baseline to $17.3 \pm 5.8 \mathrm{mmHg}$ at 12 months ( $p=0.01$ ). Success was defined as $>20 \%$, and IOP reduction was achieved in $43 \%$ of eyes at the end of the observation period. The results showed that $23 \%$ of eyes presented an IOP reduction of $44 \%$. In $20 \%$ of eyes, one medication was reduced. The researchers found no difference in age or baseline IOPs between patients who successfully responded to the procedure and those who did not. The only significant parameter was the presence of goniodysgenesis. Eyes without goniodysgenesis had a 4.3-fold (95\% CI 1.1-15.2) higher chance of appropriate IOP reduction compared with those affected by angle dysgenesis $(p=0.034)[46]$. 
Liu et al. conducted a retrospective study of 56 eyes of patients under 40 years of age with POAG and OHT in comparison with 23 eyes of patients over 60 years old. All eyes underwent SLT and were followed up for at least 12 months. While younger patients had significantly higher baseline IOPs $(p=0.02)$, IOPs at the 12-month follow-up were not significantly different between groups $(p=0.59)$. Success was defined as IOP reduction $>20 \%$ with no change in medical treatment and no need for surgery. The researchers showed success rates of $71.4 \%$ and $56.5 \%$ in young and elderly patients, respectively. The difference was not significant [47].

In both studies, SLT proved to be effective in young patients with open-angle glaucoma. Since shortening the period of topical medication use or achieving independence from it is of particular value to younger patients, further randomized controlled trials need to be promptly conducted to provide a higher grade of evidence [46,47].

\subsection{Exfoliative Glaucoma (XFG)}

XFG is the most common secondary glaucoma that has a proven worse prognosis and faster progression. Due to higher angle pigmentation that, theoretically, could result in higher efficacy, SLT may appear to be an attractive option in this group of glaucoma patients.

A small prospective, non-randomized study by Shazly showed that the efficacy of SLT as primary therapy was similar in POAG and XFG. At the 30-month follow-up, the mean IOPs in POAG and XGF groups were $17.6 \pm 2.8 \mathrm{mmHg}$ and $18.3 \pm 4.7 \mathrm{mmHg}$, respectively. The mean reduction in these groups was $5.7 \pm 2.1 \mathrm{mmHg}$ and $5.3 \pm 3.0 \mathrm{mmHg}$, respectively. The slightly lower IOP in the POAG group at the end of the observation period was not statistically significant [48].

Part of a retrospective study conducted in Sweden, known for higher rates of XFG among OAG patients, compared the efficacy of SLT between XFG and POAG patients for different indications (primary treatment, intolerance of medication, and attempt to delay other invasive treatments). The XFG and POAG groups consisted of 114 and 142 patients. The mean baseline IOP was $24.2 \pm 5.4 \mathrm{mmHg}$ and $23.3 \pm 5.9 \mathrm{mmHg}$ in POAG and XFG groups, respectively. IOP at follow-up was $19.9 \pm 5.4 \mathrm{mmHg}$ in the XFG group and $19.8 \pm 6.7 \mathrm{mmHg}$ in the POAG group. In both groups, the reduction was statistically significant $(p<0.001)$. The difference in IOP between POAG and exfoliative glaucoma patients at the baseline $(p=0.20)$ and follow-up $(p=0.26)$ was not statistically significant [49].

Similarly, Miraftabi et al. compared 20 XFG with 28 POAG eyes in a prospective study and obtained similar results in terms of the efficacy of IOP reduction in both groups at the 12-month follow-up. In their study, the percentage of IOP reduction was higher in the XFG group than in the POAG group at 6 months, and this difference was statistically significant $(p=0.02)$. This might have resulted from the higher IOP baseline in the XFG group [50].

A retrospective review of 48 POAG and 37 XFG eyes reported success rates of $54.2 \%$ and $78.4 \%$ in POAG and XFG groups at 12 months, respectively $(p=0.039)$, with SLT success rates defined as IOP $\leq 21 \mathrm{mmHg}$, reduced medical usage and a $\leq 20 \%$ reduction in IOP without additional medications. With a baseline IOP that did not differ significantly, IOP at 12 months was higher in the POAG group, and the difference was statistically significant $(p<0.0001)$. After one year, the mean IOP reduction in POAG and XFG groups was $4.4 \pm 2.1 \mathrm{~mm} \mathrm{Hg}$ and $6.1 \pm 3.6 \mathrm{mmHg}$, respectively. [51].

SLT appears to be an appropriate treatment modality in exfoliative glaucoma, proving as effective in this condition as it is in primary open-angle glaucoma.

\subsection{Pigmentary Glaucoma}

Patients with pigmentary glaucoma (PG) were included in OAG groups in a number of studies, but most of them appeared to be isolated cases. We found only one retrospective study that assessed the efficacy of SLT exclusively in PG patients. The study group consisted of 30 eyes of 30 PG patients. The primary outcome measure was time to failure after SLT, defined as any of the following: $<20 \%$ IOP reduction, change in medication, and repeated 
SLT or the need for glaucoma surgery. Time to failure was 27.4 (SD 13.61) months on average. Success rates measured by the Kaplan-Meier curve were $85 \%, 67 \%, 44 \%$ and $14 \%$ after 12, 24, 36 and 48 months, respectively. Researchers reported two cases of postoperative IOP spikes ( $>6 \mathrm{mmHg}$ ), which had diminished by the day after treatment without any change in medication. Further studies might help to clarify differences (if any) in efficacy and safety between PG and other types of glaucoma [52-55].

\subsection{Advanced Glaucoma}

Although trabeculectomy remains the "gold standard" in treating advanced glaucoma, decision-making about such invasive therapy in most clinical situations is not straightforward. In the majority of cases, clinicians need to consider the relatively high perioperative risk, especially when a reoperation is involved. As a safe and noninvasive treatment, SLT can thus be considered an option. We found two studies that showed promising results.

In their retrospective chart review of 44 eyes (44 patients), Schlote et al. assessed the efficacy of SLT in patients with subtotal papilla excavation and $\geq$ stage 3 in the Glaucoma Staging System 2 scale who underwent SLT because they had insufficient IOP control after treatment, suffered from allergies, experienced discomfort with topical medication or were non-compliant with topical treatment. For this group of patients, four success criteria were defined:

1. Reduction in IOP to $<21 \mathrm{mmHg}$ and $>20 \%$ compared with the baseline (achieved in 26 eyes, $59.1 \%$;

2. IOP reduction to $<18 \mathrm{mmHg}$ with no additional medication at all time points after SLT (achieved in 29 eyes, 65.9\%);

3. IOP reduction to $<18 \mathrm{mmHg}$ and $>30 \%$ of baseline (achieved in 22 eyes, $50 \%$ );

4. The number of eyes that underwent incisional surgery within 12 months after SLT (occurred in 8 eyes).

In this group, the mean baseline IOP was $22.1 \pm 4.1[16,35] \mathrm{mmHg}$, while the IOP at the 12-month follow-up was $14.8 \pm 2.4[10,26]$, with the difference being statistically significant $(p<0.0001)$. Eyes that underwent trabeculectomy were excluded from this statistic. The number of medications remained unchanged in the 12-month follow-up period [56].

Sharpe et al. retrospectively compared the efficacy of SLT in 53 eyes with prior trabeculectomy with an ExPress mini shunt, Ahmed valve or combined phacoemulsificationtrabeculectomy (prior glaucoma surgery, PGS group) with a matching group of 53 eyes with no prior glaucoma surgery (NPGS group). The indication for SLT was uncontrolled IOP despite maximally tolerable medical therapy. The mean pre-SLT IOP was $19.2 \pm 4.3 \mathrm{mmHg}$ in the PGS group and $20.6 \pm 6.0 \mathrm{mmHg}$ in the NPGS group. The mean IOP reduction was statistically significant in both groups at the 1- and 6-month follow-up $(p<0.04)$ and reached $7.3 \%$ in the PGS group and $10.8 \%$ in the NPGS group $(p=0.42)$ at 6 months. The success rate, defined as $>20 \%$ IOP reduction, was achieved in $28.3 \%$ and $24.5 \%$ at 1 month and $27.9 \%$ and $31.7 \%$ at 1 year in PGS and NPGS groups, respectively. In the PGS group, IOP reduction was significantly higher in eyes with a baseline IOP $\geq 21 \mathrm{mmHg}$ compared with those with IOP $<21 \mathrm{mmHg}$ at all follow-ups. In this study, success rates were significantly lower than in other studies evaluating SLT efficacy due to the advanced glaucoma stage, in which TM is heavily dysfunctional. This study shows that, among advanced glaucoma eyes, there is a group in which TM demonstrates some residual activity that can be moderated with laser therapy [57].

In contrast to this study, Zhang et al. reported a similarly defined SLT success rate of $77.7 \%$ at 9 months in patients with prior trabeculectomy and uncontrolled IOP. With 18 eyes of 16 patients, the study sample was significantly smaller than in the previously described study, and there was no control group [58]. 


\subsection{Angle Closure}

Although angle closure and angle-closure glaucoma are beyond the scope of this review, it is worth mentioning few studies with promising results that we also found in this indication.

A randomized clinical trial from 2015 compared efficacy of SLT (49 patients) versus travoprost $0.004 \%$ ( 47 patients) in reducing IOP in patients with primary angle closure (PAC) or primary angle-closure glaucoma (PACG) who underwent laser peripheral iridotomy (LPI) and in whom the angles opened in more than $180^{\circ}$. At 6 months follow-up study showed similar absolute reduction of IOP in the SLT and the travoprost group (4.0 vs. $4.2 \mathrm{~mm} \mathrm{Hg}$, respectively; $p=0.78$ ). Success defined as IOP $<21 \mathrm{~mm} \mathrm{Hg}$ and no additional medication was achieved in $60 \%$ of the eyes in the SLT group and $84 \%$ in the travoporst group $(p=0.008)$. The study proved the SLT to be effective in reducing IOP in PAC and PACG patients in short term observation [59].

A case control study from 2016 compared the efficacy of the SLT in patients with PAC or PACG in whom the angles opened in at least $180^{\circ}$ after LPI versus POAG patients. Groups were matched for age, baseline IOP and severity of glaucoma. Patients were followed up for 10 months in the PAC/PACG group and 11 months in the POAG group. At the end of follow-up, the difference in the postoperative IOP reduction was not statistically significant $(p=0.66)$. Success defined as IOP reduction of $\geq 20 \%$ from baseline or reduction in medication of 1 or more drugs was achieved in $84.7 \%$ patients in PAC/PACG group and $79.6 \%$ in POAG group $(p=0.47)$. The study showed similar efficacy of the SLT in reducing IOP in PAC/PACG patients and POAG patients [60].

A prospective study from 2019 assessed efficacy of the SLT in PAC/PACG patients with the angles opened in at least $180^{\circ}$ after LPI versus POAG patients, not only in terms of IOP reduction but also in terms of preventing glaucoma progression in a longer follow-up (6 years). The study showed similar, statistically significant IOP reduction in both groups during entire follow-up period. Glaucoma progression was assessed with the use of guided progression analysis (GPA) on Humphrey Field Analyzer II together with peripapillary retinal nerve fiber layer (RNFL) and ganglion cell complex (GCC) on FD-OCT. The study showed a significant decrease in rates of progression (ROP) according to GPA, RNFL and GCC in both groups after SLT. According to GPA, ROP was significantly faster in PAC/PACG group than in POAG groups in period between 2 to 6 years after SLT. However, the study revealed no such difference according to RNFL and GCC trend analysis. In this study, SLT was proved to be effective in preventing glaucoma progression both in PAC/PACG and POAG patients [61].

\section{Predictive Factors}

As mentioned above, SLT appears to be a generally effective procedure. However, in each trial, there was a group of patients who did not respond to the treatment. For this reason, several trials have been conducted in search of factors that enable the prediction of success. With 72 patients evaluated at their one-year follow-up, Hodge et al. demonstrated that SLT success was strongly predicted by baseline IOP (odds ratio $=1.16 ; p=0.0001$ ) and not by age, sex, glaucoma type or grade of TM pigmentation [62]. Similar results were shown in a recent retrospective review by Hirabayashi et al. [63]. In this study, at 6 months, patients with a baseline IOP $>18 \mathrm{mmHg}$ showed an IOP reduction of $5.4 \pm 5.3 \mathrm{mmHg}$ (23.7\% reduction), whereas patients with a baseline IOP $<18 \mathrm{mmHg}$ showed a reduction of $-0.7 \pm 4.6 \mathrm{mmHg}(4.9 \%$ increase; $p<0.001)$. Similarly, in this study, SLT success was not significantly predicted by age, type and severity of glaucoma, PTM or total energy delivered. These results are consistent with three other trials. The results of a post hoc analysis of the LIGHT study by Garg et al. (mentioned above in the subsection "SLT as first-line therapy") showed that early absolute IOP reduction was positively correlated with baseline IOP and negatively correlated with female gender [13,14,31,62-66].

By contrast, a Chinese trial showed that, in addition to high pre-SLT IOP (coefficient $=0.3$; OR: $1.3 ; p=0.0005$ ), older age (coefficient $=0.1 ;$ OR: $1.1 ; p=0.0003)$, the use of 
four types of antiglaucoma medication (coefficient $=2.1$; OR: 8.4; $p=0.005$ ), a higher spherical equivalent (coefficient $=2.1 ;$ OR: $8.4 ; p=0.005$ ) and the use of a topical carbonic anhydrase inhibitor (coefficient $=1.7 ;$ OR: $6.0 ; p=0.003$ ) were significantly associated with success. Additionally, in another study conducted by the same researchers in normaltension glaucoma patients, the use of three types of IOP-lowering eye drops prior to SLT was negatively associated with success rate $(p=0.02)$ [67].

In summary, the independent predictor appears to be an elevated IOP, itself achieving a reduction of $23-30 \%$. This result is comparable to the effect of topical medication and, as such, can be considered among treatments with the highest rates of IOP reduction.

\section{Repeatability}

Because the energy applied in SLT is relatively low with limited tissue damage, it is a repeatable procedure. Several trials have evaluated the efficacy and safety of repeated SLT.

Hong et al. published a retrospective chart review that analyzed the efficacy of repeated SLT (SLT 2) compared with primary SLT (SLT 1) in 44 eyes of 35 patients with POAG, XFG and PG at several time points. The study group consisted of patients older than 18 years of age whose glaucoma was not adequately controlled with maximally tolerable medical therapy and whose initial SLT procedure was successful ( $>20 \%$ IOP reduction) for at least 6 months. Patients underwent a repeated SLT once the effect of the initial SLT wore off. The only statistically significant difference in IOP after SLT 1 and SLT 2 was the mean change at $1-3$ months, which was $-5.0 \mathrm{mmHg}$ for SLT 1 and $-2.9 \mathrm{mmHg}$ for SLT 2 $(p=0.01)$. Despite its retrospective character and small study group, which included both eyes of several patients to achieve the required sample size, the study demonstrated that SLT can be repeated with success after the effect of the primary SLT wears off [68].

Another retrospective chart review by Polat et al. was similarly designed, but only one eye of 38 patients was included. The initial SLT resulted in significant IOP reduction at all follow-up observations in the 24-month period (the mean baseline IOP was 21.6 (4.8) $\mathrm{mmHg}$ vs. mean IOP at months $1-24$, ranging from 15.9 to $18.6 \mathrm{mmHg}(p<0.05))$. The mean baseline IOP of repeated SLT was 19.1 (3.9) $\mathrm{mmHg}$. This value was lower than that of the primary SLT because the decision about repeated SLT was made before the effect of the primary SLT was fully depleted. The mean IOP after the repeated SLT in the 24-month observation period ranged from 14.7 to $17.0 \mathrm{mmHg}$ and was significantly reduced from the baseline. To evaluate the median survival time, a Kaplan-Meier survival analysis was conducted, which showed a median survival time of 270 days (9 months) and 360 days (12 months) for the initial and repeated SLT, respectively, when success was defined as $>20 \%$ IOP reduction. This review showed that both initial and repeated SLT are effective in reducing IOP and that the IOP reduction achieved after the initial SLT can be restored with repeated SLT [69].

A larger sample size of 137 eyes of 137 patients and stricter success criteria were advantages of a similarly designed multi-center study by Francis et al. In the first definition, success was defined as an IOP value ranging from 5 to $21 \mathrm{mmHg}$ and IOP reduction from baseline of $>20 \%$ with no additional glaucoma medications or procedures. The second definition of success was less stringent: an IOP value of $521 \mathrm{mmHg}$, no glaucoma procedure needed and either an IOP reduction of $>20 \%$ from baseline or a reduction in medication. After SLT 1, 55\% and 35\% of eyes met the success criteria included in the first definition at 6 months and 12 months, respectively. With the second definition, the success rates were $65 \%$ and $44 \%$ at 6 and 12 months, respectively. Post-SLT 2 success rates with the first definition were $37 \%$ at 6 months and $19 \%$ at 12 months. When rated using the second definition, these values were $48 \%$ and $27 \%$, respectively. The larger sample size enabled a sub-analysis in which the success rates of repeated SLT were evaluated based on the time between the initial and repeated SLT. With either definition, repeated SLT performed less than one year after the initial SLT proved to have better success rates than repeated SLT performed more than one year after the first SLT [19]. 
The repeatability of primary SLT was evaluated in a retrospective chart review by Avery et al. and in a post hoc analysis of the SLT treatment arm in the LIGHT study by Garg et al. [31,70].

The first study included 42 eyes of 42 patients who had primary SLT that was repeated when failure of the first treatment was found. Success was defined as an IOP reduction of $\geq 20 \%$ of the baseline IOP and an IOP at or below a target that was predefined according to the grade of visual field loss. The researchers found no statistically significant difference in the percentage reduction in IOP after the first and second SLT (two-tailed paired t-test). Primary SLT was successful in 55\% of eyes, with a mean duration of success of 6.9 (3.4) months. Repeated SLT was successful in $66 \%$ of eyes, with a mean duration of success of 13.1 (11.2) months [70].

Garg et al. compared IOP values in 115 eyes of 90 patients from the LIGHT study before and 2 months after primary and repeated SLT. The baseline IOP before the initial SLT was significantly higher than IOP before the repeated SLT (mean difference of $3.4 \mathrm{mmHg}$, $95 \% \mathrm{CI}, 2.6-4.3 \mathrm{mmHg}, p<0.001)$. Although absolute IOP reduction at 2 months was greater after initial SLT compared with repeated SLT (mean difference of $1.0 \mathrm{mmHg}, 95 \% \mathrm{CI}, 0.2-$ $1.8 \mathrm{mmHg}, p=0.02$ ), the adjusted absolute IOP reduction at 2 months was greater after the repeated SLT (adjusted mean difference $1.1 \mathrm{mmHg}, 95 \% \mathrm{CI}, 1.7-0.5 \mathrm{mmHg}, p=0.001$ ). This may show the added effect of repeated SLT [31].

Due to different designs, patient characteristics, sample sizes and follow-up periods, the studies evaluating SLT repeatability are not easily comparable. Table 2 summarizes the differences.

Table 2. Summary of studies evaluating SLT repeatability.

\begin{tabular}{|c|c|c|c|c|c|}
\hline Research & $\begin{array}{c}\text { Hong et al. in } 2009 \\
{[68]}\end{array}$ & $\begin{array}{c}\text { Avery et al. in } 2013 \\
{[70]}\end{array}$ & $\begin{array}{c}\text { Francis et al. in } 2016 \\
{[19]}\end{array}$ & Polat et al. 2016 [69] & Garg et al. 2020 [31] \\
\hline Patient characteristics & $\begin{array}{c}\text { POAG, XFG, and PG } \\
\text { uncontrolled on } \\
\text { medication }\end{array}$ & $\begin{array}{l}\text { Treatment-naïve } \\
\text { POAG }\end{array}$ & $\begin{array}{c}\text { Primary and } \\
\text { secondary glaucoma } \\
\text { (except uveitic) on } \\
\text { medication }\end{array}$ & $\begin{array}{c}\text { POAG, XFG and PG } \\
\text { uncontrolled on } \\
\text { medication }\end{array}$ & $\begin{array}{l}\text { Treatment-naïve } \\
\text { OHT and OAG that } \\
\text { required repeated } \\
\text { SLT }\end{array}$ \\
\hline $\begin{array}{l}\text { Interval between 1st } \\
\text { and } 2 \text { nd SLT (time in } \\
\text { which 1st SLT } \\
\text { remained successful) }\end{array}$ & Not specified & Not specified & At least 6 months & At least 6 months & Maximum 18 months \\
\hline Sample size & 44 eyes of 35 patients & 42 eyes of 42 patients & $\begin{array}{l}137 \text { eyes of } 137 \\
\text { patients }\end{array}$ & 38 eyes of 38 patients & $\begin{array}{l}115 \text { eyes of } 90 \\
\text { patients }\end{array}$ \\
\hline Range of SLT & $360^{\circ}$ & $360^{\circ}(40-50$ spots $)$ & $360^{\circ}(80-132)$ & $360^{\circ}$ (100 spots) & $360^{\circ}$ (100 spots) \\
\hline Definition of success & $\begin{array}{l}\geq 20 \% \text { reduction from } \\
\text { baseline }\end{array}$ & $\begin{array}{c}\text { IOP reduction of } \\
\geq 20 \% \text { of baseline IOP } \\
\text { and IOP at or below } \\
\text { predefined target }\end{array}$ & $\begin{array}{l}\text { 1st definition: } \\
\text { IOP 5-21 mmHg, IOP } \\
\text { reduction }>20 \% \text {, no } \\
\text { addition of } \\
\text { medication or } \\
\text { procedure; } \\
\text { 2nd definition: } \\
\text { IOP 5-21 mmHg, no } \\
\text { additional glaucoma } \\
\text { procedure, either IOP } \\
\text { reduction of }>20 \% \text { or } \\
\text { reduction in } \\
\text { medication }\end{array}$ & $\begin{array}{c}\text { "Real-world" } \\
\text { definition: IOP } \\
\text { control without } \\
\text { additional } \\
\text { IOP-lowering } \\
\text { medications, } \\
\text { glaucoma laser } \\
\text { procedures or } \\
\text { incisional glaucoma } \\
\text { surgery; } \\
\text { "formal" definition } \\
\text { IOP reduction } \geq 20 \%\end{array}$ & $\begin{array}{c}\text { IOP at or below } \\
\text { target IOP without } \\
\text { additional } \\
\text { IOP-lowering } \\
\text { medications, further } \\
\text { laser procedures or } \\
\text { incisional glaucoma } \\
\text { surgery }\end{array}$ \\
\hline
\end{tabular}


Table 2. Cont.

\begin{tabular}{|c|c|c|c|c|c|}
\hline Research & $\begin{array}{c}\text { Hong et al. in } 2009 \\
{[68]}\end{array}$ & $\begin{array}{c}\text { Avery et al. in } 2013 \\
\text { [70] }\end{array}$ & $\begin{array}{c}\text { Francis et al. in } 2016 \\
\text { [19] }\end{array}$ & Polat et al. 2016 [69] & Garg et al. 2020 [31] \\
\hline \multirow[t]{3}{*}{$\begin{array}{c}\text { Success rate of first } \\
\text { SLT }\end{array}$} & \multirow[t]{3}{*}{$(p=0.52)$} & \multirow[t]{3}{*}{$55 \%$} & $\begin{array}{l}55 \% \text { at } 6 \text { months and } \\
34 \% \text { at } 12 \text { months; }\end{array}$ & $\begin{array}{c}\text { Not specified; } \\
\text { "real-world" } \\
\text { definition: } \\
\text { Kaplan-Meier } \\
\text { survival analysis } \\
\text { showed a median } \\
\text { survival time of } 570 \\
\text { days; }\end{array}$ & Not specified; \\
\hline & & & 2nd definition: & "Formal" definition: & $\begin{array}{l}\text { Kaplan-Meier } \\
\text { survival analysis }\end{array}$ \\
\hline & & & $\begin{array}{l}65 \% \text { at } 6 \text { months and } \\
44 \% \text { at } 12 \text { months }\end{array}$ & $\begin{array}{c}\text { Kaplan-Meier } \\
\text { survival analysis } \\
\text { showed a median } \\
\text { survival time of } 270 \\
\text { days }\end{array}$ & $\begin{array}{l}\text { showed a median } \\
\text { duration of effect of } \\
189 \text { days }\end{array}$ \\
\hline \multirow{3}{*}{$\begin{array}{l}\text { Success rate of } \\
\text { second SLT }\end{array}$} & \multirow{3}{*}{$43.2 \%(p=0.52)$} & \multirow{3}{*}{$66 \%$} & $\begin{array}{l}\text { 1st definition: } 37 \% \text { at } \\
6 \text { months and } 19 \% \text { at } \\
12 \text { months; } \\
\text { 2nd definition: } 48 \% \\
\text { at } 6 \text { months and } 27 \% \\
\text { at } 12 \text { months }\end{array}$ & $\begin{array}{l}\text { Not specified; } \\
\text { "real-world" } \\
\text { definition: }\end{array}$ & Not specified; \\
\hline & & & & $\begin{array}{c}\text { Kaplan-Meier } \\
\text { survival analysis } \\
\text { showed a median } \\
\text { survival time of } 1054 \\
\text { days; }\end{array}$ & $\begin{array}{l}\text { Kaplan-Meier } \\
\text { survival analysis } \\
\text { could not be } \\
\text { conducted, as } 50 \% \text { of } \\
\text { eyes had not reached } \\
\text { the endpoint by the } \\
\text { end of follow-up }\end{array}$ \\
\hline & & & & $\begin{array}{l}\text { "Formal" definition: } \\
\text { Kaplan-Meier } \\
\text { survival analysis } \\
\text { showed a median } \\
\text { survival time of } 360 \\
\text { days }\end{array}$ & \\
\hline \multirow[b]{2}{*}{$\begin{array}{l}\text { Time of evaluation or } \\
\text { follow-up period }\end{array}$} & \multirow[b]{2}{*}{$\begin{array}{l}\text { 5-8 months } \\
\text { follow-up }\end{array}$} & $\begin{array}{l}\text { Mean duration of } \\
\text { follow-up: }\end{array}$ & \multirow[b]{2}{*}{$\begin{array}{l}\text { 12-15 months' } \\
\text { follow-up }\end{array}$} & & \\
\hline & & $\begin{array}{l}\text { 1st SLT: mean } \\
\text { duration of follow-up } \\
\text { was } 10.5 \text { months; } \\
\text { 2nd SLT: } 15.1 \text { months; } \\
\text { 3rd SLT: } 9.0 \text { months }\end{array}$ & & up to 24 months & 18 months' follow-up \\
\hline $\begin{array}{l}\text { Mean IOP reduction } \\
\text { after 1st SLT [mmHg] }\end{array}$ & $\begin{array}{c}4.0(5.3,2.7) \text { at } 5-8 \\
\text { months }\end{array}$ & $\begin{array}{l}3.6(4.8) \text { at second } \\
\text { visit (4-5 months) }\end{array}$ & $\begin{array}{l}4.1(\mathrm{SD} 4.8) \text { at } 6-12 \\
\text { months }(p<0.001)\end{array}$ & $\begin{array}{l}2.9-5.7 \text { at different } \\
\text { points in } 24 \text {-month } \\
\text { follow-up }\end{array}$ & $\begin{array}{c}5.3(4.5-6.0)[95 \% \mathrm{CI}] \\
\text { at } 2 \text { months }\end{array}$ \\
\hline $\begin{array}{l}\text { Mean IOP reduction } \\
\text { after 2nd SLT }\end{array}$ & $\begin{array}{l}2.9(4.2,1.5) \mathrm{mmHg} \text { at } \\
5-8 \text { months }(p=0.16)\end{array}$ & $\begin{array}{l}4.5(4.5) \text { at second } \\
\text { visit (4-5 months) }\end{array}$ & $\begin{array}{l}2.9(\mathrm{SD} 4.7) \text { at } 6-12 \\
\text { months }(p<0.001)\end{array}$ & $\begin{array}{l}2.3-4.4 \text { at different } \\
\text { points in } 24 \text {-month } \\
\text { follow-up }\end{array}$ & $\begin{array}{c}4.6(4.0-5.2)[95 \% \mathrm{CI}] \\
\text { at } 2 \text { months }\end{array}$ \\
\hline
\end{tabular}

\section{Complications}

SLT is a safe procedure with a very low complication rate most of which are transient and self-limiting. The most frequent side effects mentioned in the systemic review and meta-analysis by Wong et al. were IOP spikes, anterior chamber inflammation, eye pain or discomfort, and peripheral anterior synechiae [28,71].

\subsection{IOP Spikes}

In Wong's analysis, the frequency of IOP spikes varied from 0 to $28 \%$. In the LIGHT trial, in which 776 SLTs were performed, only 6 IOP spikes were observed, of which only 1 patient required additional treatment. In their case series, Harasymowicz et al. described four cases of IOP elevation up to $46 \mathrm{mmHg}$ in patients with highly pigmented angles. Three of these patients presented features of pigment dispersion syndrome. Two patients had 
undergone ALT prior to SLT, and one patient had a history of ocular trauma. All patients required medical therapy, and three patients underwent trabeculectomy $[13,14,28,72]$.

\subsection{Anterior Chamber Inflammation}

This adverse event was evaluated as part of the West Indies Glaucoma Laser Study (WIGLS). In this study, cells and flare in the anterior chamber were observed in $40.3 \%$ and $9.7 \%$ of eyes, respectively. One patient presented bilateral anterior iritis one day after the procedure. The patient had concealed a previous history of recurrent iritis. In this case, signs of iritis were resolved after one week of topical treatment with $1 \%$ prednisolone acetate used four times a day. In all other patients, signs resolved without any treatment, as no anti-inflammatory prophylaxis was used in this study. One case of severe iritis with uveal effusion was reported [73,74].

\subsection{Eye pain, Discomfort and Redness}

Eye pain, discomfort and redness are frequently reported adverse events in many clinical trials. These mild, self-limiting symptoms are mainly related to the SLT technique $[28,71]$.

\subsection{Peripheral Anterior Synechiae}

Wong et al. reported PAS in $0-2.86 \%$ in 12 studies. Baser et al. reported two cases of PAS after repeated SLT. In both cases, PAS did not progress and IOP remained stable [75].

\subsection{Corneal Adverse Events}

We found cases of corneal edema with corneal endotheliitis, corneal haze with stromal edema and herpetic keratitis. Bettis et al. reported a case series of five XFG patients with an IOP spike, two of whom developed corneal decompensation requiring keratoplasty. Several studies have shown minor transient endothelial changes after SLT, such as a reduction in endothelial cell count and central corneal thickness or an increase in dark spots in specular microscopy [76-81].

\subsection{Other}

Other reported rare complications of SLT are hypopyon with possible herpes simplex reactivation, hyphema, cystoid macular edema in patients with diabetes, and post-ocular trauma. One case reported foveal burns resulting from the use of capsulotomy mode during SLT [74-78,82-86].

\section{Summary}

Treating glaucoma is a long-term challenge, with the probability that most patients with newly diagnosed glaucoma will be treated for the duration of their lifetime. With a range of alternatives, such as medication, laser, surgery and minimally invasive glaucoma surgery, clinicians should strive for effectiveness in terms of patient adherence; quality of life; and balanced, cost-effective therapy. Reducing the burden of medical treatment and its complications is the main objective of this struggle.

SLT has proven to be an effective and safe method for reducing IOP in newly diagnosed OAG and OHT patients. The results of the well-designed and effectively conducted LIGHT study raise the question of whether medical therapy should still be proposed as first-line therapy in OAG and OHT. Presumably, it is better to induce medical therapy only in cases of SLT failure, especially for patients with higher baseline IOPs with higher predicted IOP reductions. With an efficacy similar to the primary procedure, repeated SLT offers the valuable possibility of achieving long-lasting drop-free periods in glaucoma treatment. This might be important not only for the reduction in topical medication complications but also with regard to the frequent lack of compliance as well as problems with the application of eye drops, which is particularly troublesome for elderly glaucoma patients. 
In patients whose IOP is already controlled with topical treatment, it is possible to reduce or even discontinue medication, which enhances treatment-related quality of life. Patients with uncontrolled IOP on maximally tolerable medication can achieve the target IOP after SLT. Some reports showed partial efficacy of SLT in advanced OAG, which can be important given the high risk of postoperative complications that accompany incisional glaucoma surgery. All of the advantages of SLT described above are also of particular value to young patients, in whom SLT has been shown to be effective and who, at the time of diagnosis, face the prospect of life-long therapy and can benefit the most from delaying the introduction of other treatment modalities.

As an important limitation of the most cited studies (with exception of the LIGHT study), one should mention concentration on the IOP values as the outcome measures, whereas in real-life decision making it is the progression observed in visual field or imaging that implies possible treatment escalation. In this field further well-designed randomized trials are required [87].

Supplementary Materials: The following are available online at https:/ /www.mdpi.com/article/10 .3390/jcm10153307/s1: Supplementary Materials: Search strategy overview.

Author Contributions: Conceptualization, A.Z. and J.P.-D.; methodology, J.P.-D.; validation, A.Z., J.P.-D. and M.S.; formal analysis, A.Z. and J.P.-D.; strategy search, A.Z. and J.P.-D.; resource extraction, A.Z.; data curation, A.Z.; writing-original draft preparation, A.Z. and J.P.-D.; writing-review and editing, M.S. and A.T.-K.; visualization, A.Z. and J.P.-D.; supervision, A.T.-K.; project administration, J.P.-D.; funding acquisition, A.T.-K. All authors have read and agreed to the published version of the manuscript.

Funding: No external funding was received for the conduction of this study. The publication grant, intended to cover all publication fees, was founded by the Wroclaw Medical University Subvention for the Department of Ophthalmology (grant no. SUB.C240.21.036). No payment was received for authorship of the document.

Institutional Review Board Statement: Not applicable.

Informed Consent Statement: Not applicable.

Data Availability Statement: Not applicable.

Acknowledgments: The authors are grateful for the excellent assistance and advice of Marta MisiukHojło (Head of the Department of Ophthalmology), Department of Ophthalmology, Wroclaw Medical University, Poland. We also want to thank Karolina Krawczyk for the graphical help and the beautiful drawing in Figure 1. Proofreading and review of the final text before journal submission were performed by Richard Peters, an academic proofreader who has worked for academic clients at Charles University Prague, Palacký University Olomouc and the Education University of Hong Kong.

Conflicts of Interest: The authors declare no conflict of interest.

\section{References}

1. Heijl, A. Reduction of Intraocular Pressure and Glaucoma Progression: Results From the Early Manifest Glaucoma Trial. Arch. Ophthalmol. 2002, 120, 1268. [CrossRef]

2. Agis Investigators. The advanced glaucoma intervention study (AGIS): 7. the relationship between control of intraocular pressure and visual field deterioration. Am. J. Ophthalmol. 2000, 130, 429-440. [CrossRef]

3. Latina, M.A.; Park, C. Selective targeting of trabecular meshwork cells: In vitro studies of pulsed and CW laser interactions. Exp. Eye Res. 1995, 60, 359-371. [CrossRef]

4. Kramer, T.R.; Noecker, R.J. Comparison of the morphologic changes after selective laser trabeculoplasty and argon laser trabeculoplasty in human eye bank eyes. Ophthalmology 2001, 108, 773-779. [CrossRef]

5. Latina, M.A.; Sibayan, S.A.; Shin, D.H.; Noecker, R.J.; Marcellino, G. Q-switched 532-nm Nd:YAG laser trabeculoplasty (selective laser trabeculoplasty): A multicenter, pilot, clinical study11Dr. Mark A. Latina has financial interest in this technology. Ophthalmology 1998, 105, 2082-2090. [CrossRef]

6. Mäepea, O.; Bill, A. Pressures in the juxtacanalicular tissue and Schlemm's canal in monkeys. Exp. Eye Res. 1992, 54, 879-883. [CrossRef]

7. SooHoo, J.R.; Seibold, L.K.; Ammar, D.A.; Kahook, M.Y. Ultrastructural Changes in Human Trabecular Meshwork Tissue after Laser Trabeculoplasty. J. Ophthalmol. 2015, 2015, 476138. [CrossRef] 
8. Bradley, J.M.; Anderssohn, A.M.; Colvis, C.M.; Parshley, D.E.; Zhu, X.H.; Ruddat, M.S.; Samples, J.R.; Acott, T.S. Mediation of laser trabeculoplasty-induced matrix metalloproteinase expression by IL-1beta and TNFalpha. Investig. Ophthalmol. Vis. Sci. 2000, 41, 422-430.

9. Parshley, D.E.; Bradley, J.M.; Fisk, A.; Hadaegh, A.; Samples, J.R.; Van Buskirk, E.M.; Acott, T.S. Laser trabeculoplasty induces stromelysin expression by trabecular juxtacanalicular cells. Investig. Ophthalmol. Vis. Sci. 1996, 37, $795-804$.

10. Lee, J.Y.; Kagan, D.B.; Roumeliotis, G.; Liu, H.; Hutnik, C.M. Secretion of matrix metalloproteinase-3 by co-cultured pigmented and non-pigmented human trabecular meshwork cells following selective laser trabeculoplasty. Clin. Exp. Ophthalmol. 2016, 44, 33-42. [CrossRef]

11. Alvarado, J.A.; Katz, L.J.; Trivedi, S.; Shifera, A.S. Monocyte modulation of aqueous outflow and recruitment to the trabecular meshwork following selective laser trabeculoplasty. Arch. Ophthalmol. 2010, 128, 731-737. [CrossRef]

12. Alvarado, J.A.; Iguchi, R.; Martinez, J.; Trivedi, S.; Shifera, A.S. Similar effects of selective laser trabeculoplasty and prostaglandin analogs on the permeability of cultured Schlemm canal cells. Am. J. Ophthalmol. 2010, 150, 254-264. [CrossRef]

13. Gazzard, G.; Konstantakopoulou, E.; Garway-Heath, D.; Garg, A.; Vickerstaff, V.; Hunter, R.; Ambler, G.; Bunce, C.; Wormald, R.; Nathwani, N.; et al. Selective laser trabeculoplasty versus drops for newly diagnosed ocular hypertension and glaucoma: The LiGHT RCT. Health Technol. Assess. 2019, 23, 1. [CrossRef] [PubMed]

14. Gazzard, G.; Konstantakopoulou, E.; Garway-Heath, D.; Garg, A.; Vickerstaff, V.; Hunter, R.; Ambler, G.; Bunce, C.; Wormald, R.; Nathwani, N.; et al. Selective laser trabeculoplasty versus eye drops for first-line treatment of ocular hypertension and glaucoma (LiGHT): A multicentre randomised controlled trial. Lancet 2019, 393, 1505-1516. [CrossRef]

15. Ang, G.S.; Fenwick, E.K.; Constantinou, M.; Gan, A.T.L.; Man, R.E.K.; Casson, R.J.; Finkelstein, E.A.; Goldberg, I.; Healey, P.R.; Pesudovs, K.; et al. Selective laser trabeculoplasty versus topical medication as initial glaucoma treatment: The glaucoma initial treatment study randomised clinical trial. Br. J. Ophthalmol. 2020, 104, 813-821. [CrossRef] [PubMed]

16. Chen, E.; Golchin, S.; Blomdahl, S. A Comparison Between $90^{\circ}$ and $180^{\circ}$ Selective Laser Trabeculoplasty. J. Glaucoma 2004, 13 , 62-65. [CrossRef] [PubMed]

17. Goyal, S.; Beltran-Agullo, L.; Rashid, S.; Shah, S.P.; Nath, R.; Obi, A.; Lim, K.S. Effect of primary selective laser trabeculoplasty on tonographic outflow facility: A randomised clinical trial. Br. J. Ophthalmol. 2010, 94, 1443-1447. [CrossRef]

18. Shibata, M.; Sugiyama, T.; Ishida, O.; Ueki, M.; Kojima, S.; Okuda, T.; Ikeda, T. Clinical Results of Selective Laser Trabeculoplasty in Open-angle Glaucoma in Japanese Eyes: Comparison of 180 Degree with 360 Degree SLT. J. Glaucoma 2012, 21, 17-21. [CrossRef] [PubMed]

19. Francis, B.A.; Loewen, N.; Hong, B.; Dustin, L.; Kaplowitz, K.; Kinast, R.; Bacharach, J.; Radhakrishnan, S.; Iwach, A.; Rudavska, L.; et al. Repeatability of selective laser trabeculoplasty for open-angle glaucoma. BMC Ophthalmol. 2016, 16, 128. [CrossRef]

20. Tawfique, K.; Khademi, P.; Quérat, L.; Khadamy, J.; Chen, E. Comparison between 90-degree and 360-degree selective laser trabeculoplasty (SLT): A 2-year follow-up. Acta Ophthalmol. 2019, 97, 427-429. [CrossRef]

21. Özen, B.; Öztürk, H.; Yüce, B. Comparison of the effects of $180^{\circ}$ and $360^{\circ}$ applications of selective laser trabeculoplasty on intraocular pressure and cornea. Int. Ophthalmol. 2020, 40, 1103-1110. [CrossRef] [PubMed]

22. Nirappel, A.; Klug, E.; Ye, R.; Hall, N.; Chachanidze, M.; Chang, T.C.; Solá-Del Valle, D. Effectiveness of Selective Laser Trabeculoplasty Applied to $360^{\circ}$ vs. $180^{\circ}$ of the Angle. J. Ophthalmol. 2021, 2021. [CrossRef] [PubMed]

23. Groth, S.L.; Albeiruti, E.; Nunez, M.; Fajardo, R.; Sharpsten, L.; Loewen, N.; Schuman, J.S.; Goldberg, J.L. SALT Trial: Steroids after Laser Trabeculoplasty: Impact of Short-Term Anti-inflammatory Treatment on Selective Laser Trabeculoplasty Efficacy. Ophthalmology 2019, 126, 1511-1516. [CrossRef]

24. Jinapriya, D.; D’Souza, M.; Hollands, H.; El-Defrawy, S.R.; Irrcher, I.; Smallman, D.; Farmer, J.P.; Cheung, J.; Urton, T.; Day, A.; et al. Anti-inflammatory therapy after selective laser trabeculoplasty: A randomized, double-masked, placebo-controlled clinical trial. Ophthalmology 2014, 121, 2356-2361. [CrossRef] [PubMed]

25. Garg, A.; Vickerstaff, V.; Nathwani, N.; Garway-Heath, D.; Konstantakopoulou, E.; Ambler, G.; Bunce, C.; Wormald, R.; Barton, K.; Gazzard, G.; et al. Primary Selective Laser Trabeculoplasty for Open-Angle Glaucoma and Ocular Hypertension: Clinical Outcomes, Predictors of Success, and Safety from the Laser in Glaucoma and Ocular Hypertension Trial. Ophthalmology 2019, 126, 1238-1248. [CrossRef]

26. De Keyser, M.; De Belder, M.; De Groot, V. Randomized Prospective Study of the Use of Anti-Inflammatory Drops After Selective Laser Trabeculoplasty. J. Glaucoma 2017, 26, e22-e29. [CrossRef] [PubMed]

27. Rebenitsch, R.L.; Brown, E.N.; Binder, N.R.; Jani, A.; Bonham, A.J.; Krishna, R.; Pikey, K. Effect of topical loteprednol on intraocular pressure after selective laser trabeculoplasty for open-angle glaucoma. Ophthalmol. Ther. 2013, 2, 113-120. [CrossRef]

28. Wong, M.O.M.; Lee, J.W.Y.; Choy, B.N.K.; Chan, J.C.H.; Lai, J.S.M. Systematic review and meta-analysis on the efficacy of selective laser trabeculoplasty in open-angle glaucoma. Surv. Ophthalmol. 2015, 60, 36-50. [CrossRef]

29. Zhang, L.; Weizer, J.S.; Musch, D.C. Perioperative medications for preventing temporarily increased intraocular pressure after laser trabeculoplasty. Cochrane Database Syst. Rev. 2017, CD010746. [CrossRef]

30. Herdman, M.; Gudex, C.; Lloyd, A.; Janssen, M.F.; Kind, P.; Parkin, D.; Bonsel, G.; Badia, X. Development and preliminary testing of the new five-level version of EQ-5D (EQ-5D-5L). Qual. Life Res. 2011, 20, 1727-1736. [CrossRef]

31. Garg, A.; Vickerstaff, V.; Nathwani, N.; Garway-Heath, D.; Konstantakopoulou, E.; Ambler, G.; Bunce, C.; Wormald, R.; Barton, K.; Gazzard, G. Efficacy of Repeat Selective Laser Trabeculoplasty in Medication-Naive Open-Angle Glaucoma and Ocular Hypertension during the LiGHT Trial. Ophthalmology 2020, 127, 467-476. [CrossRef] 
32. Chi, S.C.; Kang, Y.-N.; Hwang, D.-K.; Liu, C.J. Selective laser trabeculoplasty versus medication for open-angle glaucoma: Systematic review and meta-analysis of randomised clinical trials. Br. J. Ophthalmol. 2020, 104, 1500-1507. [CrossRef] [PubMed]

33. Lai, J.S.M.; Chua, J.K.H.; Tham, C.C.Y.; Lam, D.S.C. Five-year follow up of selective laser trabeculoplasty in Chinese eyes. Clin. Exp. Ophthalmol. 2004, 32, 368-372. [CrossRef]

34. Nagar, M.; Luhishi, E.; Shah, N. Intraocular pressure control and fluctuation: The effect of treatment with selective laser trabeculoplasty. Br. J. Ophthalmol. 2009, 93, 497-501. [CrossRef] [PubMed]

35. Kiddee, W.; Atthavuttisilp, S. The effects of selective laser trabeculoplasty and travoprost on circadian intraocular pressure fluctuations. Medicine 2017, 96. [CrossRef] [PubMed]

36. Ansari, E. 10-year outcomes of first-line selective laser trabeculoplasty (SLT) for primary open-angle glaucoma (POAG). Graefe's Arch. Clin. Exp. Ophthalmol. 2021. [CrossRef]

37. Sakata, R.; Shirato, S.; Miyata, K.; Aihara, M. Incidence of deepening of the upper eyelid sulcus in prostaglandin-associated periorbitopathy with a latanoprost ophthalmic solution. Eye 2014, 28, 1446-1451. [CrossRef] [PubMed]

38. Stapleton, F.; Alves, M.; Bunya, V.Y.; Jalbert, I.; Lekhanont, K.; Malet, F.; Na, K.-S.; Schaumberg, D.; Uchino, M.; Vehof, J.; et al. TFOS DEWS II Epidemiology Report. Ocul. Surf. 2017, 15, 334-365. [CrossRef]

39. Filippopoulos, T.; Paula, J.S.; Torun, N.; Hatton, M.P.; Pasquale, L.R.; Grosskreutz, C.L. Periorbital changes associated with topical bimatoprost. Ophthalmic Plast. Reconstr. Surg. 2008, 24, 302-307. [CrossRef]

40. Francis, B.A.; Ianchulev, T.; Schofield, J.K.; Minckler, D.S. Selective laser trabeculoplasty as a replacement for medical therapy in open-angle glaucoma. Am. J. Ophthalmol. 2005, 140, 524-525. [CrossRef] [PubMed]

41. Tufan, A.K.; Onur, İ.U.; Yiğit, F.U.; Ağaçhan, A.; Aşık Nacaroğlu, Ş. Selective Laser Trabeculoplasty vs. Fixed Combinations with Timolol in Practice: A Replacement Study in Primary Open Angle Glaucoma. Turk. J. Ophthalmol. 2017, 47, 198-204. [CrossRef] [PubMed]

42. De Keyser, M.; De Belder, M.; De Belder, J.; De Groot, V. Selective laser trabeculoplasty as replacement therapy in medically controlled glaucoma patients. Acta Ophthalmol. 2018, 96, e577-e581. [CrossRef] [PubMed]

43. De Keyser, M.; De Belder, M.; De Groot, V. Quality of life in glaucoma patients after selective laser trabeculoplasty. Int. J. Ophthalmol. 2017, 10, 742-748. [CrossRef] [PubMed]

44. Patel, V.; El Hawy, E.; Waisbourd, M.; Zangalli, C.; Shapiro, D.M.; Gupta, L.; Hsieh, M.; Kasprenski, A.; Katz, L.J.; Spaeth, G.L. Long-term outcomes in patients initially responsive to selective laser trabeculoplasty. Int. J. Ophthalmol. 2015, 8, 960-964. [CrossRef]

45. Khawaja, A.P.; Campbell, J.H.; Kirby, N.; Chandwani, H.S.; Keyzor, I.; Parekh, M.; McNaught, A.I.; Vincent, D.; Angela, K.; Nitin, A.; et al. Real-World Outcomes of Selective Laser Trabeculoplasty in the United Kingdom. Ophthalmology 2020, 127, 748-757. [CrossRef] [PubMed]

46. Gupta, V.; Ghosh, S.; Sujeeth, M.; Chaudhary, S.; Gupta, S.; Chaurasia, A.K.; Sihota, R.; Gupta, A.; Kapoor, K.S. Selective laser trabeculoplasty for primary open-angle glaucoma patients younger than 40 years. Can. J. Ophthalmol. 2018, 53, 81-85. [CrossRef] [PubMed]

47. Liu, D.; Chen, D.; Tan, Q.; Xia, X.; Jiang, H.; Jiang, J. Outcome of Selective Laser Trabeculoplasty in Young Patients with Primary Open-Angle Glaucoma and Ocular Hypertension. J. Ophthalmol. 2020, 2020, 5742832. [CrossRef]

48. Shazly, T.A.; Smith, J.; Latina, M.A. Long-term safety and efficacy of selective laser trabeculoplasty as primary therapy for the treatment of pseudoexfoliation glaucoma compared with primary open-angle glaucoma. Clin. Ophthalmol. 2011, 5, 5-10. [CrossRef]

49. Belitsky, Y.; Škiljić, D.; Zetterberg, M.; Kalaboukhova, L. Evaluation of selective laser trabeculoplasty as an intraocular pressure lowering option. Acta Ophthalmol. 2019, 97, 707-713. [CrossRef]

50. Miraftabi, A.; Nilforushan, N.; Nassiri, N.; Nouri-Mahdavi, K. Selective laser trabeculoplasty in patients with pseudoexfoliative glaucoma vs primary open angle glaucoma: A one-year comparative study. Int. J. Ophthalmol. 2016, 9, 406-410. [CrossRef]

51. Kara, N.; Altan, C.; Yuksel, K.; Tetikoglu, M. Comparison of the efficacy and safety of selective laser trabeculoplasty in cases with primary open-angle glaucoma and pseudoexfoliative glaucoma. Kaohsiung J. Med. Sci. 2013, 29, 500-504. [CrossRef]

52. Ayala, M. Long-term Outcomes of Selective Laser Trabeculoplasty (SLT) Treatment in Pigmentary Glaucoma Patients. J. Glaucoma 2014, 23, 616-619. [CrossRef]

53. McAlinden, C. Selective laser trabeculoplasty (SLT) vs other treatment modalities for glaucoma: Systematic review. Eye 2014, 28, 249-258. [CrossRef] [PubMed]

54. Nagar, M.; Ogunyomade, A.; O’Brart, D.P.S.; Howes, F.; Marshall, J. A randomised, prospective study comparing selective laser trabeculoplasty with latanoprost for the control of intraocular pressure in ocular hypertension and open angle glaucoma. $\mathrm{Br}$. $\mathrm{J}$. Ophthalmol. 2005, 89, 1413-1417. [CrossRef]

55. McIlraith, I.; Strasfeld, M.; Colev, G.; Hutnik, C.M.L. Selective Laser Trabeculoplasty as Initial and Adjunctive Treatment for Open-Angle Glaucoma. J. Glaucoma 2006, 15, 124-130. [CrossRef]

56. Schlote, T.; Kynigopoulos, M. Selective laser trabeculoplasty (SLT): 1-year results in early and advanced open angle glaucoma. Int. Ophthalmol. 2016, 36, 55-61. [CrossRef] [PubMed]

57. Sharpe, R.A.; Kammerdiener, L.L.; Williams, D.B.; Das, S.K.; Nutaitis, M.J. Efficacy of selective laser trabeculoplasty following incisional glaucoma surgery. Int. J. Ophthalmol. 2018, 11, 71-76. [CrossRef] [PubMed] 
58. Zhang, H.; Yang, Y.; Xu, J.; Yu, M. Selective laser trabeculoplasty in treating post-trabeculectomy advanced primary open-angle glaucoma. Exp. Ther. Med. 2016, 11, 1090-1094. [CrossRef]

59. Narayanaswamy, A.; Leung, C.K.; Istiantoro, D.V.; Perera, S.A.; Ho, C.-L.; Nongpiur, M.E.; Baskaran, M.; Htoon, H.M.; Wong, T.T.; Goh, D.; et al. Efficacy of selective laser trabeculoplasty in primary angle-closure glaucoma: A randomized clinical trial. JAMA Ophthalmol. 2015, 133, 206-212. [CrossRef] [PubMed]

60. Ali Aljasim, L.; Owaidhah, O.; Edward, D.P. Selective Laser Trabeculoplasty in Primary Angle-closure Glaucoma after Laser Peripheral Iridotomy: A Case-Control Study. J. Glaucoma 2016, 25, e253-e258. [CrossRef] [PubMed]

61. Kurysheva, N.I.; Lepeshkina, L.V. Selective Laser Trabeculoplasty Protects Glaucoma Progression in the Initial Primary OpenAngle Glaucoma and Angle-Closure Glaucoma after Laser Peripheral Iridotomy in the Long Term. BioMed Res. Int. 2019, 2019, 4519412. [CrossRef]

62. Hodge, W.G.; Damji, K.F.; Rock, W.; Buhrmann, R.; Bovell, A.M.; Pan, Y. Baseline IOP predicts selective laser trabeculoplasty success at 1 year post-treatment: Results from a randomised clinical trial. Br. J. Ophthalmol. 2005, 89, 1157-1160. [CrossRef] [PubMed]

63. Hirabayashi, M.; Ponnusamy, V.; An, J. Predictive Factors for Outcomes of Selective Laser Trabeculoplasty. Sci. Rep. 2020, 10, 9428. [CrossRef] [PubMed]

64. Alaghband, P.; Galvis, E.A.; Daas, A.; Nagar, A.; Beltran-Agulló, L.; Khawaja, A.P.; Goyal, S.; Lim, K.S. Predictors of selective laser trabeculoplasty success in open angle glaucoma or ocular hypertension: Does baseline tonography have a predictive role? Br. J. Ophthalmol. 2020, 104, 1390-1393. [CrossRef]

65. Chun, M.; Gracitelli, C.P.B.; Lopes, F.S.; Biteli, L.G.; Ushida, M.; Prata, T.S. Selective laser trabeculoplasty for early glaucoma: Analysis of success predictors and adjusted laser outcomes based on the untreated fellow eye. BMC Ophthalmol. 2016, 16, 206. [CrossRef]

66. Pillunat, K.R.; Spoerl, E.; Elfes, G.; Pillunat, L.E. Preoperative intraocular pressure as a predictor of selective laser trabeculoplasty efficacy. Acta Ophthalmol. 2016, 94, 692-696. [CrossRef] [PubMed]

67. Lee, J.W.; Liu, C.C.; Chan, J.C.; Wong, R.L.; Wong, I.Y.; Lai, J.S. Predictors of success in selective laser trabeculoplasty for primary open angle glaucoma in Chinese. Clin. Ophthalmol. 2014, 8, 1787-1791. [CrossRef]

68. Hong, B.K.; Winer, J.C.; Martone, J.F.; Wand, M.; Altman, B.; Shields, B. Repeat selective laser trabeculoplasty. J. Glaucoma 2009, 18, 180-183. [CrossRef] [PubMed]

69. Polat, J.; Grantham, L.; Mitchell, K.; Realini, T. Repeatability of selective laser trabeculoplasty. Br. J. Ophthalmol. 2016, 100, 1437-1441. [CrossRef]

70. Avery, N.; Ang, G.S.; Nicholas, S.; Wells, A. Repeatability of primary selective laser trabeculoplasty in patients with primary open-angle glaucoma. Int. Ophthalmol. 2013, 33, 501-506. [CrossRef] [PubMed]

71. Song, J. Complications of selective laser trabeculoplasty: A review. Clin. Ophthalmol. 2016, 10, 137-143. [CrossRef] [PubMed]

72. Harasymowycz, P.J.; Papamatheakis, D.G.; Latina, M.; De Leon, M.; Lesk, M.R.; Damji, K.F. Selective Laser Trabeculoplasty (SLT) Complicated by Intraocular Pressure Elevation in Eyes with Heavily Pigmented Trabecular Meshworks. Am. J. Ophthalmol. 2005, 139, 1110-1113. [CrossRef] [PubMed]

73. Realini, T.; Shillingford-Ricketts, H.; Burt, D.; Balasubramani, G.K. West Indies Glaucoma Laser Study (WIGLS) 3. Anterior Chamber Inflammation Following Selective Laser Trabeculoplasty in Afro-Caribbeans with Open-Angle Glaucoma. J. Glaucoma 2019, 28, 622-625. [CrossRef] [PubMed]

74. Kim, D.Y.; Singh, A. Severe Iritis and Choroidal Effusion Following Selective Laser Trabeculoplasty. Ophthalmic Surg. Lasers Imaging Retin. 2008, 39, 409-411. [CrossRef]

75. Baser, E.F.; Akbulut, D. Significant peripheral anterior synechiae after repeat selectıve laser trabeculoplasty. Can. J. Ophthalmol. 2015, 50, e36-e38. [CrossRef] [PubMed]

76. Liu, E.T.; Seery, L.S.; Arosemena, A.; Lamba, T.; Chaya, C.J. Corneal edema and keratitis following selective laser trabeculoplasty. Am. J. Ophthalmol. Case Rep. 2017, 6, 48-51. [CrossRef]

77. Wood, S.D.; Elam, A.; Moroi, S. Rare corneal complication following selective laser trabeculoplasty. Am. J. Ophthalmol. Case Rep. 2018, 10, 28-31. [CrossRef]

78. Chadha, N.; Belyea, D.A.; Grewal, S. Herpetic Stromal Keratitis following Selective Laser Trabeculoplasty. Case Rep. Ophthalmol. Med. 2016, 2016, e5768524. [CrossRef]

79. Bettis, D.I.; Whitehead, J.J.; Farhi, P.; Zabriskie, N.A. Intraocular Pressure Spike and Corneal Decompensation Following Selective Laser Trabeculoplasty in Patients with Exfoliation Glaucoma. J. Glaucoma 2016, 25, e433. [CrossRef]

80. Lee, J.W.Y.; Chan, J.C.H.; Chang, R.T.; Singh, K.; Liu, C.C.L.; Gangwani, R.; Wong, M.O.M.; Lai, J.S.M. Corneal changes after a single session of selective laser trabeculoplasty for open-angle glaucoma. Eye 2014, 28, 47-52. [CrossRef]

81. Ong, K.; Ong, L.; Ong, L. Corneal endothelial changes after selective laser trabeculoplasty. Clin. Exp. Ophthalmol. 2013, 41, 537-540. [CrossRef] [PubMed]

82. Koenig, L.R.; Kovacs, K.D.; Gupta, M.P.; Van Tassel, S.H. Hypopyon following selective laser trabeculoplasty. Am. J. Ophthalmol. Case Rep. 2020, 18, 100675. [CrossRef]

83. Rhee, D.J.; Krad, O.; Pasquale, L.R. Hyphema following selective laser trabeculoplasty. Ophthalmic Surg. Lasers Imaging Retin. 2009, 40, 493-494. [CrossRef] [PubMed] 
84. Ha, J.H.; Bowling, B.; Chen, S.D. Cystoid macular oedema following selective laser trabeculoplasty in a diabetic patient. Clin. Exp. Ophthalmol. 2014, 42, 200-201. [CrossRef]

85. Liyanage, S.E.; Kumaran, N.; Alwis, D.D. Macular burns resulting from the accidental use of selective laser trabeculoplasty mode during a laser capsulotomy. Br. J. Ophthalmol. 2014, 98, 141-142. [CrossRef] [PubMed]

86. Örnek, N.; Örnek, K.; Oğurel, T.; Büyüktortop Gökçınar, N. Cystoid macular edema following selective laser trabeculoplasty in a patient with ocular hypertension. Int. Ophthalmol. 2019, 39, 1891-1893. [CrossRef]

87. Wright, D.M.; Konstantakopoulou, E.; Montesano, G.; Nathwani, N.; Garg, A.; Garway-Heath, D.; Crabb, D.P.; Gazzard, G.; Laser in Glaucoma and Ocular Hypertension Trial (LiGHT) Study Group. Visual Field Outcomes from the Multicenter, Randomized Controlled Laser in Glaucoma and Ocular Hypertension Trial (LiGHT). Ophthalmology 2020, 127, 1313-1321. [CrossRef] 